\title{
OMSET USAHA DAN SISTEM INFORMASI AKUNTANSI PADA USAHA PEMPEK DI PALEMBANG
}

\author{
Yohanes Andri Putranto Bernadus \\ Universitas Katolik Musi Charitas \\ andri@ukmc.ac.id
}

\begin{abstract}
Abstrak: Omset Usaha dan Sistem Informasi Akuntansi pada Usaha Pempek di Palembang. Dalam dekade terakhir, Palembang sering menjadi tempat penyelenggaraan kompetisi olahraga tingkat nasional dan internasional. Hal ini berdampak meningkatnya popularitas salah satu makanan khas Palembang yaitu Pempek. Kondisi ini berpengaruh signifikan pada perkembangan usaha pempek di Kota Palembang. Meningkatnya omset usaha memiliki dampak pada meningkatnya kompleksitas pengelolaan transaksi. Berdasarkan fenomena ini, penelitian ini bertujuan menguji secara empiris pengaruh omset usaha terhadap penerapan sistem informasi akuntansi. Penelitian empiris dilakukan dengan menggunakan data dari 100 usaha pempek di Kota Palembang. Data dikumpulkan dengan menggunakan kuesioner. Hasilnya adalah omset usaha berpengaruh signifikan positif terhadap penerapan sistem informasi akuntansi. Temuan ini mendukung teori kontingensi dalam penerapan sistem informasi akuntansi. Semakin besar omset usaha berdampak pada peningkatan kompleksitas pengelolaan transaksi bisnis. Kondisi ini mendorong munculnya kebutuhan pemilik usaha pempek untuk menerapkan sisitem informasi akuntansi. Penelitian ini memiliki implikasi praktik untuk usaha pempek terkait dengan siklus akuntansi apa yang memerlukan penerapan sistem informasi akuntansi baik pada usaha dengan omset yang relatif kecil dan usaha dengan omset yang relatif besar.
\end{abstract}

Kata kunci: omset usaha, sistem informasi akuntansi, dan usaha pempek

Abstract: Business Turnover and Accounting Information Systems at Pempek Business in Palembang. In the last decade, Palembang has often been the venue for national and international sports competitions. This has an impact on the growing popularity of one of Palembang's typical foods, Pempek. This condition has a significant impact on the development of the pempek business in Palembang City. Increased business turnover can have an impact on increasing the complexity of managing transactions. Based on this phenomenon, this study aims to empirically examine the effect of business turnover on the application of accounting information systems. An empirical study was conducted using data from 100 pempek businesses in Palembang City. Data was collected using a questionnaire. The result is business turnover that significantly positively affects the implementation of accounting information systems. These results support the contingency theory in the implementation of accounting information systems. The greater turnover of a business has an impact on the increasing complexity of managing business transactions. This research has practical implications for Pempek businesses related to the accounting cycle that requires the application of accounting information systems both in businesses with relatively small turnover and businesses with relatively large turnover.

Keywords: business turnover, accounting information systems, pempek business

\section{PENDAHULUAN}

Dalam dekade terakhir, Palembang sering menjadi tempat penyelenggaraan kompetisi olahraga tingkat nasional dan internasional. Hal ini berdampak pada semakin terkenalnya salah satu makanan khas Kota Palembang yaitu Pempek. Karena semakin banyak orang yang mengenal 


\section{Nominal: Barometer Riset Akuntansi dan Manajemen}

P-ISSN: 2303-2065 E-ISSN: 2502-5430

Volume 9 No 2 (2020)

kuliner ini, maka pempek dikukuhkan menjadi hidangan terpopuler di Indonesia dalam Anugrah Pesona Indonesia 2016 yang diselenggarakan Kementrian Pariwisata (Republika.co.id, 2019). Kondisi ini sangat berdampak signifikan pada perkembangan usaha kuliner pempek di Kota Palembang. Pada tahun 2013 saja, satu toko kecil di salah satu sentra pempek di Palembang mampu meraih omset lebih kurang Rp 25.000.000 per minggu (Tribun Sumsel, 2013). Pada tahun 2018, setiap harinya pengerajin pempek memproduksi 6,4 ton pempek dengan berbagai varian (Tempo.co, 2018) dan dalam sebulan 7 ton pempek dikirim ke luar negeri (Travel.kompas.com, 2018).

Peningkatan omset penjualan dapat berdampak pada peningkatan kompleksitas pengelolaan transaksi. Hal ini juga dapat berlaku pada usaha pempek di Palembang. Beberapa contoh dampak dari peningkatan omset adalah meningkatnya jumlah transaksi penjualan yang harus dicatat, ukuran sediaan menjadi semakin besar, biaya tenaga kerja meningkat, dan semakin komplek dalam perhitungan harga pokok penjualan. Sehingga pemilik yang selama ini hanya mengandalkan informasi berdasarkan ingatan dalam pengambilan keputusan bisnisnya sejalan dengan peningkatan kompleksitas transaksi bisnisnya akan relatif membutuhkan sistem informasi akuntansi untuk dapat mengelola data transaksinya. Hal ini sejalan dengan hasil survei yang dilakukan peneliti pada tahun 2018 terhadap 100 usaha pempek di Palembang yang menunjukkan bahwa 47\% usaha pempek yang melakukan penyusunan laporan keuangan setiap bulannya.

Omset juga secara empiris sudah diteliti mempengaruhi penerapan sistem informasi akuntansi (Ahmad \& Mohamed Zabri, 2015; Al-dmour, Al-dmour, \& Masa'deh, 2016; Andriani \& Zuliyati, 2015; Azudin \& Mansor, 2017; Damana \& Suardikha, 2016; Eri, 2013; Holmes \& Nicholls, 1988; Spencer, 2016; Tanrim, 2013). Besar kecilnya omset juga berdampak pada munculnya kebutuhan informasi akuntansi yang memadai. Semakin besar omset usaha maka semakin kompleks pengelolaan transaksi akuntansinya. Kompleksitas transaksi ini mendorong munculnya kebutuhan penyediaan informasi akuntansi. Karena semakin besar omset maka akan berdampak pada semakin besar kemampuan keuangan perusahaan. Perusahaan yang mempunyai kemampuan keuangan yang baik akan dengan mudah untuk menerapkan sistem informasi akuntansi.

Berdasarkan uraian di atas, peneliti termotivasi untuk menguji secara empiris apakah omset usaha berpengaruh positif terhadap penerapkan sistem informasi akuntansi pada usaha pempek. Usaha 
pempek yang akan diteliti adalah usaha pempek yang berada di Kota Palembang.

\section{KAJIAN LITERATUR}

\section{Faktor Kontingensi}

Dalam konteks sistem informasi akuntansi, desain sistem informasi akuntansi adalah merupakan renspon terhadap faktorfaktor kontingensi (Nicolaou, 2000). Salah satu faktor kontingensi yang mempengaruhi sistem informasi akuntansi antara lain ukuran perusahaan/omset usaha (Ahmad \& Mohamed Zabri, 2015; Azudin \& Mansor, 2017). Perusahaan dengan omset besar memiliki sistem informasi akuntansi yang lebih kompleks. Jika dikaitkan dengan penelitian ini, maka usaha pempek yang menerapkan sistem informasi akuntansi dipengaruhi oleh faktor kondisional yang dihadapi (kontingensi) yaitu omset perusahaan. Omset perusahaan merupakan pemicu terjadi perubahan dalam suatu organisasi yang berdampak pada solusi bisnis yang baru yang sesuai dengan kondisi terkini yang sedang hadapi.

\section{Sistem Informasi Akuntansi}

Sistem informasi akuntansi merupakan elemen penting dalam keberlanjutan suatu usaha khususnya usaha kecil dan menengah (UKM). Hal ini dikarenakan sistem informasi akuntansi mendukung aktivitasaktivitas bisnis dengan menyediakan informasi yang berguna dalam pengambilan keputusan-keputusan bisnis yang terkait dengan aktivitas-aktivitas bisnis tersebut. Sistem informasi akuntansi dapat menjadi sistem manual pensil dan kertas, sistem kompleks yang menggunakan teknologi informasi terbaru, atau sesuatu diantaranya (Romney \& Steinbart, 2017).

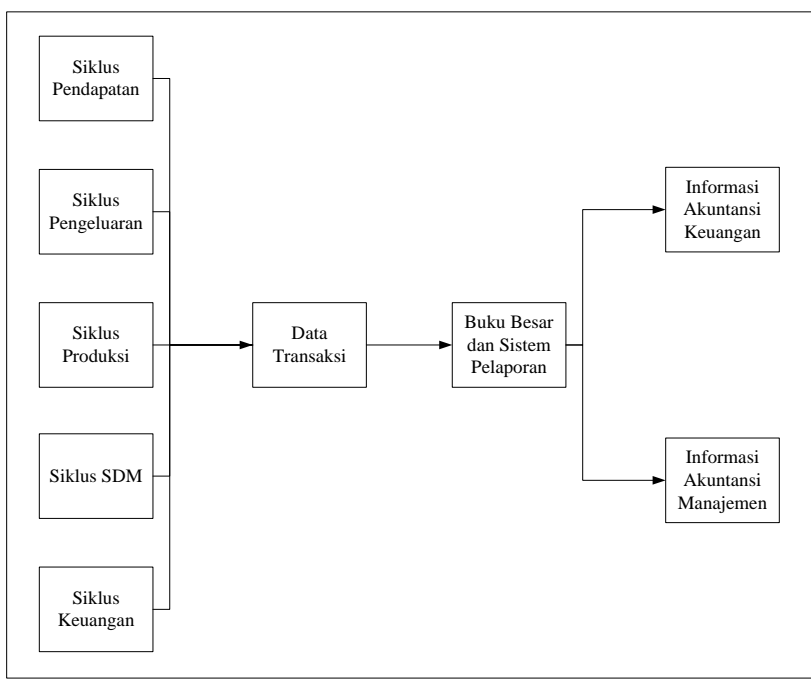

Gambar 1: Skema Sistem Informasi Akuntansi

Sistem informasi akuntansi adalah suatu sistem informasi yang mengumpulkan, mencatat, menyimpan, dan memproses data akuntansi dan data lainnya untuk menghasilkan informasi untuk para pembuat keputusan (Romney \& Steinbart, 2018). Sistem informasi akuntansi merupakan bagian dari sistem informasi manajemen (Hartono, 2013). Sistem informasi akuntansi terdiri dari siklus pendapatan, siklus pengeluaran, siklus produksi, siklus sumber daya manusia, siklus keuangan, dan buku besar dan sistem pelaporan (Romney \& Steinbart, 2018). Siklus pendapatan 


\section{Nominal: Barometer Riset Akuntansi dan Manajemen}

P-ISSN: 2303-2065 E-ISSN: 2502-5430

Volume 9 No 2 (2020)

berhubungan dengan kegiatan penjualan barang atau jasa dan penerimaan kas atas penjualan tersebut. Siklus pengeluaran berhubungan dengan kegiatan pembelian barang atau jasa dan pembayaran kas atas pembelian tersebut. Siklus produksi berhubungan dengan kegiatan menghitung biaya yang dikeluarkan untuk menghasilkan barang atau jasa. Siklus sumber daya manusia terkait dengan penggajian. Siklus keuangan terkait dengan aktivitas pendanaan dan investasi. Buku besar dan sistem pelaporan memproses data dari setiap siklussiklus akuntansi menjadi informasi yang berguna bagi pembuat keputusan. Gambaran umum sistem informasi akuntansi disajikan pada gambar 1 .

\section{Pengembangan Hipotesis}

Omset usaha merupakan faktor kontingensi bagi perusahaan ketika suatu perusahaan membuat keputusan menerapkan sistem informasi akuntansi. Besarnya omset berdampak pada munculnya kebutuhan informasi akuntansi yang memadai. Semakin besar omset usaha pempek maka semakin kompleks pengelolaan transaksi akuntansinya. Kompleksitas transaksi ini mendorong munculnya kebutuhan penyediaan informasi akuntansi. Omset juga sering digunakan sebagai proksi untuk ukuran perusahaan (Tanrim, 2013; Eri, 2013). Semakin besar omset maka akan berdampak pada semakin besar kemampuan keuangan perusahaan. Perusahaan yang mempunyai kemampuan keuangan yang baik akan dengan mudah untuk menerapkan sistem informasi akuntansi. Berdasarkan penalaran ini maka dirumuskanlah hipotesis sebagai berikut:

Ha: Omset usaha pempek mempengaruhi secara positif penerapan sistem informasi akuntansi

\section{METODE PENELITIAN}

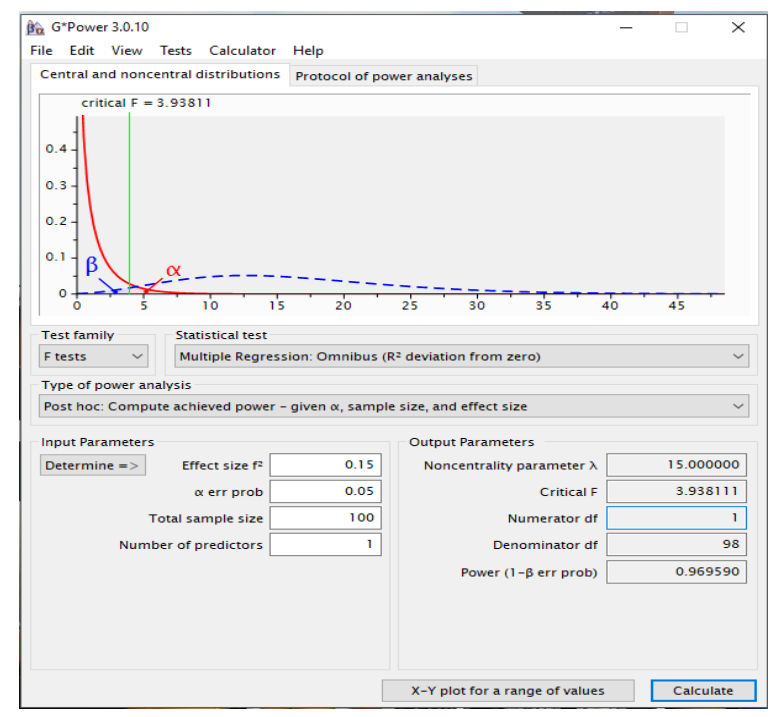

Gambar 2: Perhitugan Sampel dan Power of Test Menggunakan G*Power

Populasi penelitian ini adalah usaha pempek di Kota Palembang. Teknik pengambilan sampel menggunakan convenience sampling. Jumlah sampel yang akan diambil adalah 100 usaha pempek. Jumlah sampel sebanyak 100 usaha pempek sudah memberikan tingkat power of test yang memadai yaitu sebesar $96,7 \%$. Nilai power of test yang baik adalah lebih besar dari $80 \%$ 


\section{Nominal: Barometer Riset Akuntansi dan Manajemen \\ P-ISSN: 2303-2065 E-ISSN: 2502-5430 \\ Volume 9 No 2 (2020)}

(Wilson Von Voorhis \& Morgan, 2007). Perhitungan power of test menggunakan aplikasi G*Power 3.0.10 seperti yang disajikan pada gambar 2. Data penelitian berjenis data primer. Data primer diperoleh langsung dari pemilik usaha pempek dengan menggunakan kuesioner.

Tabel 1: Indikator Pengukuran Variabel Penerapan SIA

\begin{tabular}{|c|c|c|}
\hline No. & Siklus & Indikator \\
\hline 1 & Pendapatan & $\begin{array}{l}\text { Saat terjadi transaksi } \\
\text { penjualan, saya selalu } \\
\text { mencatatnya pada } \\
\text { buku penjualan }\end{array}$ \\
\hline 2 & Penggajian & $\begin{array}{lr}\text { Saat } & \text { penggajian } \\
\text { karyawan, } & \text { saya selalu } \\
\text { melihat } & \text { catatan / } \\
\text { laporan } & \text { kinerja } \\
\text { karyawan } & \\
\end{array}$ \\
\hline 3 & Pengeluaran & $\begin{array}{l}\text { Saat pembayaran } \\
\text { hutang, saya selalu } \\
\text { melihat catatan hutang } \\
\text { perusahaan }\end{array}$ \\
\hline 4 & Produksi & $\begin{array}{l}\text { Dalam penentuan } \\
\text { harga barang, saya } \\
\text { selalu melihat catatan } \\
\text { produksi, harga beli } \\
\text { bahan, hingga biaya- } \\
\text { biaya lainnya }\end{array}$ \\
\hline 5 & $\begin{array}{l}\text { Pelaporan } \\
\text { Akuntansi } \\
\text { Keuangan }\end{array}$ & $\begin{array}{l}\text { Laporan keuangan } \\
\text { selalu dibuat setiap } \\
\text { akhir bulan }\end{array}$ \\
\hline
\end{tabular}

Penerapan sistem informasi akuntansi adalah variabel dependen dalam penelitian ini. Penerapan sistem informasi akuntansi adalah penilaian pemilik usaha terhadap penerapan sistem informasi akuntansi pada siklus-siklus akuntansi. Pemilik usaha diminta memberikan jawab iya atau tidak atas pertanyaan-pertanyaan terkait dengan penerapan sistem informasi akuntansi dalam perusahaannya. Siklus akuntansi yang ditanyakan adalah siklus pendapatan, siklus penggajian, siklus pengeluaran, siklus produksi, dan pelaporan akuntansi keuangan. Data variabel ini berupa jumlah penerapan SIA pada usaha pempek untuk siklus yang ditanyakan.

Omset usaha adalah variabel independen. Omset usaha adalah besarnya penjulan kotor suatu usaha pempek per bulan. Skala data yang digunakan adalah skala data nominal atau dummy. Kode dan kategori data jawaban responden terdiri dari 0 untuk omset $<100$ juta Rupiah dan 1 untuk omset > 100 juta Rupiah.

Pengujian hipotesis menggunakan uji statistik Two Way ANOVA. Tingkat signifikansi penerimaan hipotesis adalah $5 \%$.

\section{HASIL PENELITIAN DAN \\ PEMBAHASAN}

\section{Statistik Deskriptif}

Pada tabel 2 disajikan frekuensi umur usaha dan omset usaha per bulan 100 usaha pempek yang menjadi sampel penelitian. Hanya 6\% saja sampel adalah perusahaan yang umur usahanya kurang dari 1 tahun dan selebihnya umur usaha lebih dari 1 tahun. Sebaran terbanyak yaitu sebesar $42 \%$ adalah pada umur usaha antara 1 sampai dengan 5 tahun. Sampel didominasi oleh usaha 
pempek yang memiliki omset kurang dari Rp 100.000.000 yaitu sebesar $89 \%$.

Tabel 2: Frekuensi Umur Usaha dan Omset Usaha

\begin{tabular}{|c|c|c|c|}
\hline & Keterangan & $\mathbf{N}$ & $\%$ \\
\hline & $<1$ tahun & 6 & $6 \%$ \\
\hline & $1-5$ tahun & 42 & $42 \%$ \\
\hline $\begin{array}{l}\text { Umur } \\
\text { Usaha }\end{array}$ & $6-10$ tahun & 19 & $19 \%$ \\
\hline & $>10$ tahun & 33 & $33 \%$ \\
\hline & Total & 100 & $100 \%$ \\
\hline & $<$ Rp100.000.000 & 89 & $89 \%$ \\
\hline Usaha & $>$ Rp100.000.000 & 11 & $11 \%$ \\
\hline & Total & 100 & $100 \%$ \\
\hline
\end{tabular}

Tabel 3 menyajikan persentase penerapan SIA dilihat dari umur usaha dan omset usaha per bulan usaha pempek yang menjadi sampel. Persentase penerapan SIA menunjukkan secara rata-rata sejauh mana usaha pempek menerapkan SIA untuk kelima siklus yang ditanyakan yaitu siklus pendapatan, siklus penggajian, siklus pengeluaran, siklus produksi, dan siklus pelaporan akuntansi keuangan. Usaha pempek yang memiliki omset per bulan diatas $\mathrm{Rp}$ 100.000.000 menerapkan SIA untuk ke semua siklus yang ditanyakan pada umur usaha kurang dari 1 tahun, 1 - 5 tahun, dan 6 - 10 tahun. Pada usaha pempek yang umur usahanya diatas 10 tahun walupun tidak $100 \%$ menerapkan SIA kepada kelima siklus yang dimaksud namun angka sebesar $88 \%$ menunjukkan bahwa usaha pempek telah menerapkan SIA untuk 4 sampai 5 siklus yang ditanyakan. Sedangkan usaha pempek yang omset usaha per bulan kurang dari Rp 100.000.000 rata-rata menerapkan SIA hanya $61 \%$ atau hanya menerapkan lebih kurang ke 3 siklus saja. Penerapan SIA terendah pada perusahaan yang umur usahanya 6 - 10 tahun yaitu sebesar 52\%.

Tabel 3: Persentase Penerapan SIA dilihat dari Umur Usaha dan Omset Usaha

\begin{tabular}{|c|c|c|c|}
\hline $\begin{array}{l}\text { Umur } \\
\text { Usaha }\end{array}$ & Omset Usaha & $\begin{array}{c}\% \\
\text { Penerapan } \\
\text { SIA }\end{array}$ & $\mathbf{N}$ \\
\hline \multirow{3}{*}{$<1$ tahun } & $<$ Rp100.000.000 & $68 \%$ & 5 \\
\hline & $>$ Rp100.000.000 & $100 \%$ & 1 \\
\hline & Total & $73 \%$ & 6 \\
\hline \multirow{3}{*}{$\begin{array}{l}1- \\
\text { tahun }\end{array}$} & $<$ Rp100.000.000 & $62 \%$ & 41 \\
\hline & $5 \overline{>\mathrm{Rp} 100.000 .000}$ & $100 \%$ & 1 \\
\hline & Total & $63 \%$ & 42 \\
\hline \multirow{3}{*}{$\begin{array}{l}6- \\
\text { tahun }\end{array}$} & $<\operatorname{Rp} 100.000 .000$ & $52 \%$ & 18 \\
\hline & $0 \overline{>\mathrm{Rp} 100.000 .000}$ & $100 \%$ & 1 \\
\hline & Total & $55 \%$ & 19 \\
\hline \multirow{4}{*}{$>10$ tahun } & $<\mathrm{Rp} 100.000 .000$ & $65 \%$ & 25 \\
\hline & १>Rp100.000.000 & $88 \%$ & 8 \\
\hline & Total & $70 \%$ & 33 \\
\hline & $<\operatorname{Rp} 100.000 .000$ & $61 \%$ & 89 \\
\hline \multirow[t]{2}{*}{ Total } & $>$ Rp100.000.000 & $91 \%$ & 11 \\
\hline & Total & $65 \%$ & 100 \\
\hline
\end{tabular}

Lebih jauh pada tabel 4 menyajikan presentase usaha pempek yang menerapkan SIA untuk kelima siklus yang ditanyakan 


\section{Nominal: Barometer Riset Akuntansi dan Manajemen}

P-ISSN: 2303-2065 E-ISSN: 2502-5430

Volume 9 No 2 (2020)

dilihat dari umur usaha dan omset usaha per bulan. Semua usaha pempek yang omset usaha per bulan lebih besar Rp 100.000.000 pada keempat kelompok umur usaha telah menerapkan SIA pada siklus pengeluaran dan siklus produksi. Sedangkan untuk usaha pempek yang omset usaha per bulan kurang dari Rp 100.000.000 pada keempat kelompok umur usaha banyaknya perusahaan yang menerapkan SIA cukup beragam. Walupun demikian, nampak bahwa jumlah usaha pempek yang menerapkan SIA pada siklus produksi adalah yang paling banyak dibanding pada siklus yang lain.

Pada usaha pempek yang umur usahanya kurang dari satu tahun memiliki persentase terbesar atas penerapan SIA pada kelima siklus akuntansi yaitu sebesar $73 \%$ dan memiliki persentase terbesar terbanyak untuk usaha pempek yang menerapkan SIA pada siklus akuntansi yang ditanyakan yaitu sebanyak tiga siklus yang dalam hal ini siklus pendapatan sebesar $83 \%$, siklus pengeluaran $67 \%$, dan siklus penyusunan laporan keuangan sebanyak 83\%. Hal ini mengindikasikan bahwa kebutuhan penerapan SIA usaha pempek yang umur usaha kurang dari satu tahun lebih besar dibandingkan usaha pempek yang umur usahanya lebih lama. Holmes \& Nicholls (1988) dalam penelitiannya juga menemukan bahwa penerapan SIA lebih banyak dan signifikan pada UKM yang umur usahanya lebih muda dibandingkan dengan UKM yang umur usahanya sudah lama karena UKM yang umur usahanya masih mudah menerapkan SIA untuk melawan UKM yang umur usahanya sudah lama. Usaha pempek yang baru berdiri menyadari persaingan yang harus dihadapi sehingga menerapkan SIA adalah salah satu cara untuk mampu bersaing. Pemilik membutuhkan informasi akuntansi untuk memantau perkembangan usahanya dan mendukung pembuatan keputusan-keputusan bisnisnya.

Dari keempat siklus, persentase terbesar usaha pempek yang menerapkan SIA ada pada siklus produksi untuk umur usahanya 1 - 5 tahun (90\%), 6 - 10 tahun (89\%), dan > 10 tahun (85\%). Dengan kata lain hampir semua usaha pempek yang usianya lebih dari 1 tahun menerapkan SIA untuk siklus produksi. Usaha pempek yang udah lama beroperasi tentunya sudah mengenal pelanggannya dan bahkan memiliki pelanggan tetap. Ketersediaan produk ketika ada permintaan dari pelanggan dan varian produk baru adalah hal yang penting untuk bisa mempertahankan pelanggan. Untuk mengelola ketersediaan produk erat kaitannya dengan siklus produksi. Romney \& Steinbart (2018) menjelaskan tujuan utama siklus produksi adalah mendesain produk yang sesuai dengan kebutuhan pelanggan dan ketersediaan produk untuk memenuhi permintaan yang ada dan permintaan 


\section{Nominal: Barometer Riset Akuntansi dan Manajemen \\ P-ISSN: 2303-2065 E-ISSN: 2502-5430 \\ Volume 9 No 2 (2020)}

potensial secara efisien. Sehingga tersedianya informasi akuntansi pada siklus produksi akan sangat membantu pemilik usaha pempek untuk mengelola siklus produksi

Tabel 4: Persentese Usaha Pempek yang Menerapkan SIA dilihat dari Umur Usaha dan Omset Per Bulan

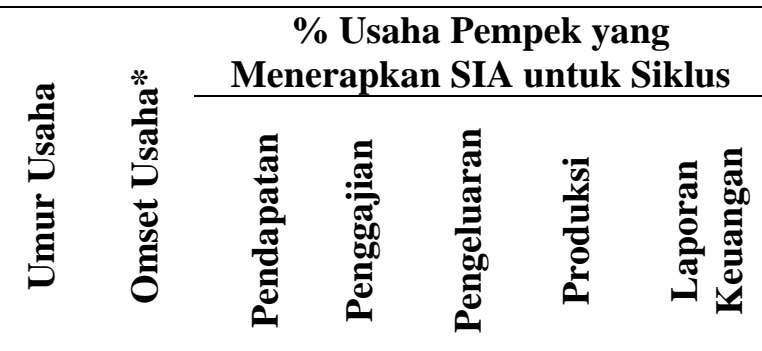

\begin{tabular}{rlrrrrr}
\hline & $<100$ & $80 \%$ & $60 \%$ & $60 \%$ & $60 \%$ & $80 \%$ \\
\hline$>100$ & $100 \%$ & $100 \%$ & $100 \%$ & $100 \%$ & $100 \%$ \\
\hline
\end{tabular} tahun \begin{tabular}{ccccccc}
$>100$ & $100 \%$ & $100 \%$ & $100 \%$ & $100 \%$ & $100 \%$ \\
\cline { 2 - 6 } & Total & $83 \%$ & $67 \%$ & $67 \%$ & $67 \%$ & $83 \%$ \\
\hline
\end{tabular}

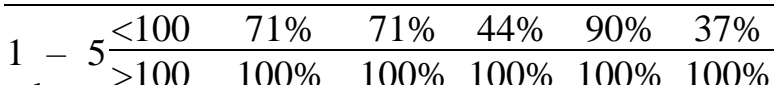
tahun \begin{tabular}{ccccccc}
$>100$ & $100 \%$ & $100 \%$ & $100 \%$ & $100 \%$ & $100 \%$ \\
\cline { 2 - 6 } & Total & $71 \%$ & $71 \%$ & $45 \%$ & $90 \%$ & $38 \%$ \\
\hline
\end{tabular} \begin{tabular}{ccccccc}
\hline $6-10<100$ & $56 \%$ & $56 \%$ & $44 \%$ & $89 \%$ & $28 \%$ \\
\hline & $>100$ & $100 \%$ & $100 \%$ & $100 \%$ & $100 \%$ & $100 \%$
\end{tabular} tahun \begin{tabular}{ccccccc}
$>100$ & $100 \%$ & $100 \%$ & $100 \%$ & $100 \%$ & $100 \%$ \\
\cline { 2 - 6 } & Total & $58 \%$ & $58 \%$ & $47 \%$ & $89 \%$ & $32 \%$
\end{tabular} $>10$\begin{tabular}{cccccc}
$<100$ & $60 \%$ & $60 \%$ & $56 \%$ & $80 \%$ & $56 \%$ \\
\hline$>100$ & $88 \%$ & $88 \%$ & $100 \%$ & $100 \%$ & $75 \%$ \\
\hline
\end{tabular}

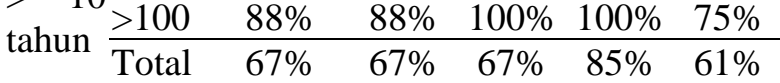

\begin{tabular}{ccccccc}
\hline \multirow{3}{*}{ Total } & $<100$ & $65 \%$ & $65 \%$ & $48 \%$ & $85 \%$ & $43 \%$ \\
\cline { 2 - 7 } & $>100$ & $91 \%$ & $91 \%$ & $100 \%$ & $100 \%$ & $82 \%$ \\
\cline { 2 - 7 } & & & &
\end{tabular}

* dalam juta Rupiah

\section{Hasil}

Pengujian hipotesis menggunakan uji statistik Two Way ANOVA dengan tingkat signifikansi penerimaan hipotesis adalah $5 \%$. Sebelum melangkah ke pengujian hipotesis, langkah pertama yang perlu dilakukan adalah pengujian asumsi kesamaan variansi kesalahan antar grup dalam model atau sering disebut homogeneity variances. Pengujian kesamaan variansi kesalahaan dilakukan dengan melihat signifikasi hasil Levene's Test. Pada tabel 5 disajikan hasil Levene's Test. Karena signifikasi Levene's Test 0,114 yang dalam hal ini lebih besar dari 0,05 maka dapat disimpulkan bahwa model memenuhi asumsi homogeneity variances.

Tabel 5: Hasil Levene' Test untuk Kesamaan Variansi Kesalahan

$$
\begin{array}{cc}
\hline \mathbf{F} & \text { Signifikansi } \\
\hline 2,541 & 0,114 \\
\hline \text { Selanjutnya dilakukan pengujian }
\end{array}
$$
hipotesis dengan menggunakan Two Way ANOVA. Hasil pengujian Two Way ANOVA disajikan pada tabel 6. Omset usaha ditemukan terbukti mempengaruhi penerapan sistem informasi akuntansi karena tingkat signifikasi nilai $\mathrm{F}$ lebih kecil dari 0,05. Skor R Squared juga memberikan nilai yang memuaskan yaitu 0,71 .

Tabel 6:Hasil Pengujian Two Way Anova

\begin{tabular}{lcc}
\hline & F & Signifikasi \\
\hline Intercept & 1101,794 & $0,000^{*}$ \\
\hline Omset usaha & 7,433 & $0,008^{*}$
\end{tabular}

R Squared $\quad 0,71$

*Signifikan pada level 5\%

\section{Pembahasan}

Hasil pengujian hipotesis memberikan bukti empiris bahwa omset usaha berpengaruh positif signifikan terhadap penerapan sistem informasi akuntansi. Dengan omset usaha terbukti mempengaruhi 


\section{Nominal: Barometer Riset Akuntansi dan Manajemen \\ P-ISSN: 2303-2065 E-ISSN: 2502-5430 \\ Volume 9 No 2 (2020)}

penerapan sistem informasi akuntansi juga mengindikasikan bahwa kompleksitas kegiatan usaha pempek yang dikarenakan meningkatnya omset usaha pempek mendorong kebutuhan penerapan sistem informasi akuntansi dalam mendukung kegiatan usaha.

Tabel 7: Persentase Penerapan SIA dan Persentase Usaha Pempek yang Menerapkan SIA Berdasarkan Omset Usaha

\begin{tabular}{|c|c|c|c|c|c|c|}
\hline \multirow{3}{*}{ 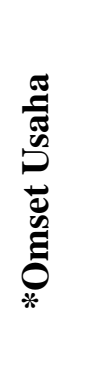 } & \multirow{3}{*}{ 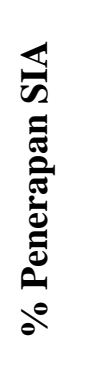 } & \multirow{2}{*}{\multicolumn{5}{|c|}{$\begin{array}{l}\% \text { Usaha Pempek yang } \\
\text { Menerapkan SIA untuk Siklus }\end{array}$}} \\
\hline & & & & & & \\
\hline & & 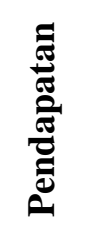 & 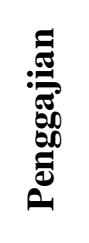 & 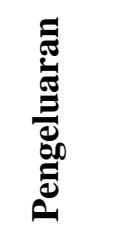 & 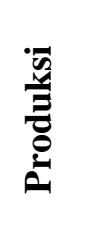 & 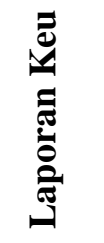 \\
\hline$<100$ & $61 \%$ & $65 \%$ & $65 \%$ & $48 \%$ & $85 \%$ & $43 \%$ \\
\hline$>100$ & $91 \%$ & $91 \%$ & $82 \%$ & $100 \%$ & $100 \%$ & $82 \%$ \\
\hline Total & $65 \%$ & $68 \%$ & $67 \%$ & $54 \%$ & $87 \%$ & $47 \%$ \\
\hline
\end{tabular}

Omset terbukti secara empiris mempengaruhi penerapan SIA pada usaha pempek di Palembang dalam penelitian ini. Pada tabel 7 nampak jelas bahwa terdapat perbedaan persentese luasnya penerapan SIA antara usaha pempek beromset < Rp100.000.000 yaitu 61\% dengan usaha pempek beromset > Rp100.000.000 yaitu 91\%. Dan perbedaan persentase usaha pempek yang menerapkan SIA pada siklus yang ditanyakan antara usaha pempek untuk usaha pempek yang beromset < Rp100.000.000 dengan usaha pempek yang beromset > Rp100.000.000. Hasil ini mendukung argumentasi bahwa semakin besar omset suatu usaha maka berdampak pada meningkatnya kompleksitas pengelolaan transaksi bisnis. Kondisi ini mendorong munculnya kebutuhan pemilik untuk menerapkan SIA. Usaha pempek yang memiliki omset besar tentunya juga akan lebih mudah untuk dapat menerapkan SIA tersebut karena memiliki kemampuan keuangan yang memadai. Sehingga jika merujuk pada tabel 7, wajar jika hampir semua usaha pempek yang besar atau yang beromset diatas Rp100.000.000 per bulan sudah menerapkan SIA pada setiap siklus akuntansi. Hasil penelitian ini mendukung hasil penelitian sebelumnya yang menemukan bahwa omset usaha berpengaruh pada penerapan SIA (Ahmad \& Mohamed Zabri, 2015; Holmes \& Nicholls, 1988).

Selain penerapan SIA pada usaha pempek yang berskala besar atau beromset di atas Rp100.000.000, peneliti juga menemukan bahwa usaha pempek kecil juga telah menerapkan SIA. Pada tabel 7 menunjukkan bahwa rata-rata penerapan SIA dalam kelima siklus akuntansi untuk usaha pempek berskala kecil adalah 61\%. Yang artinya usaha pempek berskala kecil juga telah menerapkan SIA untuk lebih kurang 3 siklus akuntansi. Berdasarkan hal ini, dapat dikatakan bahwa usaha pempek yang berskala kecil atau omset di bawah 


\section{Nominal: Barometer Riset Akuntansi dan Manajemen}

P-ISSN: 2303-2065 E-ISSN: 2502-5430

Volume 9 No 2 (2020)

Rp100.000.000 per bulan sudah menggunakan informasi akuntansi dalam pengambilan keputusan usahanya. Pada tabel 7 juga memberikan gambaran bahwa pada usaha pempek berskala kecil, penerapan SIA terbanyak pada siklus produksi yaitu sebanyak 85\%. Dengan demikian, pada usaha pempek yang berskala kecil juga membutuhkan informasi akuntansi biaya terkait kegiatan produksi dalam mendukung pengambilan keputusan penetapan harga.

\section{SIMPULAN DAN SARAN}

Penelitian ini bertujuan untuk melakukan pengujian secara empiris pengaruh omset usaha terhadap penerapan sistem informasi akuntansi. Hasil pengujian hipotesis dengan menggunakan Two Way ANOVA pada tingkat signifikasi sebesar $5 \%$ ditemukan bahwa omset usaha terbukti berpengaruh secara signifikan terhadap penerapan sistem informasi akuntansi. Dengan demikian hasil penelitian ini menyimpulkan bahwa alasan usaha pempek menerapkan sistem informasi akuntansi adalah besar kecilnya omset usaha pempek. Hasil ini memberikan bukti empiris bahwa omset usaha pada usaha pempek merupakan faktor kontingensi yang mempengaruhi penerapan sistem informasi akuntansi. Semakin besar omset suatu usaha maka berdampak pada meningkatnya kompleksitas pengelolaan transaksi bisnis. Kondisi ini mendorong munculnya kebutuhan pemilik untuk menerapkan SIA. Usaha pempek yang memiliki omset besar tentunya juga akan lebih mudah untuk dapat menerapkan SIA tersebut karena memiliki kemampuan keuangan yang memadai.

Usaha pempek yang relatif beromset besar, hampir semuanya menerapkan SIA pada setiap siklus akuntansi. Sedangkan pada usaha pempek yang relatif beromset kecil, hampir semuanya menerapkan SIA untuk siklus produksi. Hal ini memberikan implikasi bahwa usaha pempek baik yang relatif beromset besar dan beromset kecil membutuhkan informasi akuntansi dalam mengelola usahanya, khususnya untuk akuntansi biaya pada siklus produksi untuk mendukung keputusan penetapan harga produk.

Penelitian ini memiliki keterbatasan yang perlu diperhatikan oleh peneliti selanjutnya khususnya jika ingin kembali meneliti usaha pempek di Palembang. Perbandingan antara jumlah usaha pempek yang omsetnya di bawah $\mathrm{Rp}$ 100.000.000 dengan usaha pempek yang beromset di atas Rp 100.000.000 yang cukup jauh yaitu $11: 89$. Peneliti selanjutnya mungkin dapat mempertimbangkan kategori omset berdasarkan UU No.20 tahun 2008.

\section{DAFTAR PUSTAKA}

Ahmad, K., \& Mohamed Zabri, S. (2015). Factors explaining the use of management accounting practices in 
Malaysian medium-sized firms. Journal of Small Business and Enterprise Development, 22(4), 762-781. https://doi.org/10.1108/JSBED-042012-0057

Al-dmour, A., Al-dmour, R., \& Masa'deh, R. (2016). Interrelated Factors Influencing the Adoption Decision of AIS Applications by SMEs in Jordan. International Business Research, 9(10), 46-62.

https://doi.org/10.5539/ibr.v9n10p46

Andriani, N., \& Zuliyati. (2015). FaktorFaktor yang Mempengaruhi Penggunaan Informasi Akuntansi (Studi pada UMKM Kain Tenun Ikat Troso Jepara). In Prosiding Seminar Nasional Kebangkitan Teknologi 2015 (pp. 4152).

Azudin, A., \& Mansor, N. (2017). Management accounting practices of SMEs: The impact of organizational DNA, business potential and operational technology. Asia Pacific Management Review. https://doi.org/10.1016/j.apmrv.2017.0 7.014

Damana, A. W. A., \& Suardikha, I. M. S. (2016). Pengaruh Keterlibatan Pemakai, Pelatihan, Ukuran Organisasi Dan Keahlian Pemakai Terhadap Kinerja Sistem Informasi Akuntansi. E-Jurnal Akuntansi Universitas Udayana, 14, 1452-1480.

Eri, F. (2013). Analisa Hubungan Antara Intensitas Persaingan, Ukuran Perusahaan, Organisasi Pembelajaran dengan Penggunaan Sistem Informasi Akuntansi Pada Sektor Ritel di Surabaya. Business Accounting Review, 1(1).

Hartono, J. (2013). Sistem Teknologi Informasi Bisnis: Pendekatan Strategis. Jakarta: Salemba Empat.
Holmes, S., \& Nicholls, D. (1988). An Analysis of the Use of Accounting Information by Australian Small Business. Journal of Small Business Management, 26(2), 57-68. Retrieved from

http://search.ebscohost.com/login.aspx ?direct $=$ true $\& \mathrm{db}=$ buh $\& A N=5269963 \&$ site $=$ ehost-live

Nicolaou, A. I. (2000). A Contingency Model of Perceived Effectiveness in Accounting Information Systems: Organizational Coordination and Control Effects. International Journal of Accounting Information Systems, 1(2), 91-105. https://doi.org/10.1016/S14670895(00)00006-3

Republika.co.id. (2019). Pempek Dikukuhkan Jadi Hidangan Tradisional Terpopuler di Indonesia. Retrieved March 25, 2019, from https://republika.co.id/berita/gayahidup/kuliner/16/09/20/ods2to328pempek-dikukuhkan-jadi-hidangantradisional-terpopuler-di-indonesia

Romney, M. B., \& Steinbart, P. J. (2017). Sistem Informasi Akuntansi (13th ed.). Jakarta: Penerbit Salemba Empat.

Romney, M. B., \& Steinbart, P. J. (2018). Accounting Information Systems (14th ed.). Pearson Education.

Spencer, D. S. (2016). An Investigation of the Relationships between Contingency Factors Affecting the Adoption, Implementation, and Use of ActivityBased Costing in Hospital Accounting.

Tanrim, B. (2013). Analisa Hubungan Intensitas Persaingan, Ukuran Perusahaan, dan Organisasi Pembelajaran dengan Penggunaan Sistem Informasi Akuntansi Pada Sektor Industri Manufaktur di Surabaya. Business Accounting Review, 1(1). 
Tempo.co. (2018). Produksi Harian 6,4 Ton Pempek, Palembang Masih Kekurangan Ikan. Retrieved March 25, 2019, from https://bisnis.tempo.co/read/1078914/pr oduksi-harian-64-ton-pempekpalembang-masih-kekuranganikan/full\&view $=$ ok

Travel.kompas.com. (2018). Dalam Sebulan, 7 Ton Pempek Palembang Dikirim ke Luar Negeri. Retrieved March 25, 2019, from https://travel.kompas.com/read/2018/08 /09/090000327/dalam-sebulan-7-tonpempek-palembang-dikirim-ke-luarnegeri-

Tribun Sumsel. (2013). Bisnis Pempek Tembus Rp 15 M. Retrieved March 25, 2019 , from http://sumsel.tribunnews.com/2013/08/ 04/bisnis-pempek-tembus-rp-15-m

Wilson Von Voorhis, C. R., \& Morgan, B. L. (2007). Understanding Power and Rules of Thumb for Determining Sample Sizes. Tutorial in Quantitative Methods for Psychology, 3(2), 43-50. https://doi.org/10.20982/tqmp.03.2.p04 3 